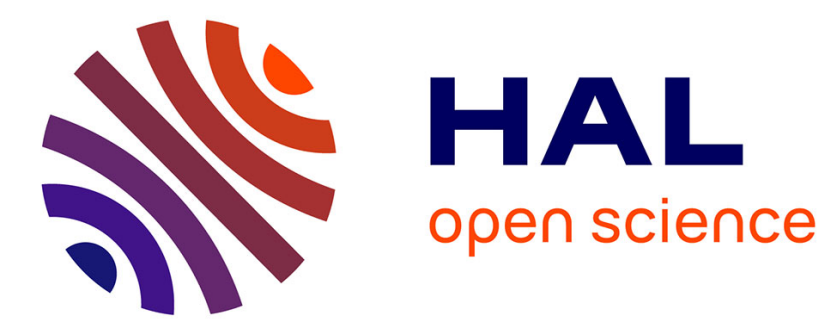

\title{
The puzzle of mobility and access to the city in Sub-Saharan Africa
}

Lourdes Diaz Olvera, Didier Plat, Pascal Pochet

\section{To cite this version:}

Lourdes Diaz Olvera, Didier Plat, Pascal Pochet. The puzzle of mobility and access to the city in SubSaharan Africa. Journal of Transport Geography, 2013, 32, pp.56-64. 10.1016/j.jtrangeo.2013.08.009 . halshs-00861105

\section{HAL Id: halshs-00861105 https://shs.hal.science/halshs-00861105}

Submitted on 16 Apr 2014

HAL is a multi-disciplinary open access archive for the deposit and dissemination of scientific research documents, whether they are published or not. The documents may come from teaching and research institutions in France or abroad, or from public or private research centers.
L'archive ouverte pluridisciplinaire HAL, est destinée au dépôt et à la diffusion de documents scientifiques de niveau recherche, publiés ou non, émanant des établissements d'enseignement et de recherche français ou étrangers, des laboratoires publics ou privés. 
Diaz Olvera L., Plat D., Pochet P. (2013), The puzzle of mobility and access to the city in sub-Saharan Africa, Journal of Transport Geography, Vol. 32, pp. 56-64.

\title{
The puzzle of mobility and access to the city in Sub-Saharan Africa
}

\author{
Lourdes Diaz Olvera, Didier Plat, Pascal Pochet \\ lourdes.diaz-olvera@entpe.fr, didier.plat@entpe.fr, pascal.pochet@entpe.fr
}

Laboratoire d'Economie des Transports

Université de Lyon (ENTPE, Université Lumière Lyon 2, CNRS)

Rue Maurice Audin, 69518 Vaulx-en-Velin Cedex,

France

\section{Introduction}

The continuous and rapid population increase in the major cities of sub-Saharan Africa is currently mainly due to natural growth. The increase in the amount of circular migration and the rebalancing of movements between towns and the countryside are resulting in migratory balances that are only slightly positive, or even negative, particularly in the case of conurbations which are high up in the urban hierarchy (Beauchemin and Bocquier, 2004; Potts, 2009). These phenomena are largely due to the increasingly difficult living conditions in African metropolises, where access to urban activities and resources is an essential factor for economic and social integration. Being able to travel to the different parts of the metropolitan area is particularly important as the number of jobs is limited and infrastructure and basic services are in short supply in many residential areas (Dorier-Apprill et al., 1998; Myers, 2005; Rakodi, 2005). The result is an increasing need for motorized travel in order to leave one's neighbourhood and visit more distant locations, in particular the city centre and other activity centres. At the same time, access to the city is becoming more and more expensive and complicated because of the increasing distances involved and the inadequate nature of the transport system in relation to the travel needs and financial resources of urban dwellers, particularly the most disadvantaged (Diaz Olvera et al., 2008; Vasconcellos, 2001). Apart from the day-to-day difficulties that are created by inadequate transport supply, a number of studies on the links between poverty and transport show that factors which impede mobility also limit access to the resources which are necessary to escape from poverty (Bryceson et al., 2003; Lucas, 2011; Salon and Gulyani, 2010; Sitrass 2004a, 2004b).

In spite of the number of problems related to urban travel (congestion, pollution and accidents), planners and decision-makers in the cities of the South still seem to have little interest in gaining a better understanding of daily travel behaviour. Historically, urban 
stakeholders have been more concerned about building more road infrastructure than providing public transport services (Vasconcellos, 2001). In addition, transport measures are often implemented in a patchy manner with no consideration of the interrelations between spatial planning and transport (Dimitriou and Gakenheimer, 2011). In the countries of the North, specific daily travel surveys are conducted periodically in order to obtain up-to-date and useful data that highlight the issues associated with transport and planning policies (Orfeuil, 2000). The situation is quite different in many countries of the South, particularly in sub-Saharan Africa, where empirical data on daily mobility remain rare and little is known about the practical conditions of access to urban activities and urban areas.

This paper sets out to improve our knowledge and understanding of access to the city and its resources by examining the daily travel behaviour of urban dwellers. The results of a secondary analysis of six household travel surveys conducted with very similar methodologies in capital cities in West Africa (Ouagadougou, Bamako, Niamey, Dakar, Conakry) and a large city in Central Africa (Douala) between 1992 and 2003 are presented. The statistical results are filled out and enriched by comments from semi-structured interviews of poor urban dwellers conducted in Conakry and Douala in 2003. Their comments provide a snapshot of mobility in the six studied cities from the 1990s to the mid-2000s, and reveal shared features and specific characteristics with regard to daily mobility and access to the city.

Section 2 outlines the methodology used in the household surveys we have analyzed. Section 3 gives a brief description of the local transport systems and the use of transport modes. Section 4 analyses daily mobility from the perspective of trip purposes and the location of out-of-home activities. The concluding section considers the social risks inherent in the limited use of urban space and the role of transport.

\section{Surveys with a similar methodology}

The household travel surveys ${ }^{1}$ all applied a similar methodology (Diaz Olvera et al., 1998, 1999; Sitrass 2004a, 2004b; Syscom, 2001). The six surveys each covered a representative sample of the households in the urban area. The study area was stratified on the basis of the availability of urban services, the date of urbanization, the distance to the centre and major roads, and the standard of living of the residents. The survey zones were then selected within the different types of stratified areas and lastly, the sample of households was selected randomly within the survey zones. To give an example, the 60 districts of Niamey were divided into five groups and within each group between 3 and 7 survey zones were selected. Twenty-six households were surveyed at home in each of these twenty-nine zones.

The earliest surveys were conducted in the cities with less than a million inhabitants while the more recent ones dealt with larger metropolises (Table 1). The sample sizes were determined partly by financial and material considerations, but statistical representativeness was sought in all cases. In order to reflect the socio-demographic structure of populations more closely, raked weights were computed, using population census data when they were available and official large-scale household surveys when they were not. The questionnaires were

\footnotetext{
${ }^{1}$ The authors participated in all the projects for which the surveys were conducted. Except in the case of Dakar, they were closely involved in specifying the methodology used for the household travel survey and the semi-structured survey, organizing the fieldwork and subsequent analyses. The Dakar survey was conducted by Syscom, a local consultancy firm, and one of the authors provided methodological assistance throughout the project. The findings presented in this paper are the outcome of comparative secondary analyses undertaken by the authors.
} 
administered by local survey staff. The field work was organized in a similar way in the different cities, but the specific features and constraints of each context were nevertheless taken into account (Behrens et al., 2006).

Table 1. The household travel surveys

\begin{tabular}{lcccc}
\hline \multicolumn{1}{c}{ City } & Year & $\begin{array}{c}\text { Estimated population } \\
\text { at the survey date } \\
\text { (million inhabitants) }\end{array}$ & $\begin{array}{c}\text { Number of households } \\
\text { surveyed }\end{array}$ & $\begin{array}{c}\text { Number of individuals of } \\
\text { over 13 years of age } \\
\text { surveyed }\end{array}$ \\
\hline Bamako (Mali) & 1993 & 0.8 & 251 & 1,666 \\
Conakry (Guinea) & 2003 & 1.7 & 627 & 2,439 \\
Dakar (Senegal) & 2000 & 2.5 & 2,301 & 8,658 \\
Douala (Cameroon) & 2003 & 2.0 & 600 & 1,749 \\
Niamey (Niger) & 1996 & 0.6 & 757 & 2,732 \\
Ouagadougou (Burkina Faso) & 1992 & 0.8 & 753 & 3,862 \\
\hline
\end{tabular}

The core of the questionnaires was very similar in all cases and included:

- The characteristics of the household and its dwelling, provided by the household's reference individual (usually the head of household or his/her spouse);

- Personal characteristics, requested from each household member of over 13 years of age (more than 10 years of age in Conakry and Douala), including access to means of transport, income and transport expenditure (the latter was not included in Bamako and Dakar);

- The characteristics of all the trips made on the day before the interview (Monday to Saturday), as described by each respondent. A trip was defined as a movement from one place to another, in order to perform an activity. For example, going to school in the morning, returning home after lessons, going shopping in one's district and coming back, all counted as trips. Thus, origins and destinations, transport modes, departure and arrival times, the activity performed at the destination and public transport expenditure were all systematically collected. The interviewers were given special training on how to identify and collect data on pedestrian trips, including very short ones, which are often underestimated in urban travel studies.

Daily mobility is generally expressed in terms of the number of trips per day and per person, broken down according to a number of criteria. By collecting details about the travel of individual members of a household, interdependencies and trade-offs with regard to travel patterns can be observed within the household. The fact that the sampling methodology and field work were the same as was the basic content of the questionnaire guarantees data comparability.

With the exception of Dakar, semi-structured interviews were conducted in all the cities. However, in the paper we shall only use those from Conakry and Douala, which are more recent. Thirty semi-structured interviews of poor city dwellers were conducted in each city by local sociologists, according to a clearly identified line of questioning with factual and openended items. The interviews revolved around three main topics: identifying travel difficulties and personal mobility strategies; the location of schools, health-care centres and markets and the mode of transport used to travel to them; social practices and associational networks and the role that transport plays in this area. The interviewees were chosen to ensure diversity in terms of gender, employment status, and residential location. 


\section{The illusion of modal choice}

The six cities share the same problems, to different degrees. Their uncontrolled spatial growth has resulted in the existence of a considerable number of unplanned settlements and the absorption of what were once villages. Cities such as Dakar, Conakry and Douala are over thirty kilometres wide in their longest direction. Jobs are still relatively concentrated in the centre, and the new districts, which are increasingly distant from the centre, lack facilities of all types (water, drainage, schools, health centres, etc.). In Bamako, at the time the survey was conducted, many households set up home on the right bank of the river in spite of the lack of facilities. Most of the administrations, secondary schools and higher education establishments, the industrial zone and the two main markets were on the left bank (ENSUP, 1993). In the outskirts of Ouagadougou, major development projects (subdivision, water, electricity) had been initiated in the preceding decade, but had failed to satisfy the needs of the population (Jaglin, 1994). In Conakry, densely populated peripheral municipalities, which lacked a hospital, were also very short of health centres (Groupe Huit-Bceom, 2003). In all cases, the transport system compensated very inadequately for the spatial imbalances in the availability of urban facilities.

\subsection{Deficiencies in transport supply}

The road system, which is inadequate and in very poor condition, does not successfully serve the under-equipped peripheral settlements. The primary road network has many shortcomings which lead to a large number of bottlenecks. In Ouagadougou, in spite of attempts to improve the road network during the period prior to the survey, the condition of only $20 \%$ of the paved roads was good, while that of $20 \%$ was acceptable and $60 \%$ poor. In the river cities of Bamako and Niamey, the fact that there was just one bridge across the rivers was responsible for even heavier congestion at the time the surveys were conducted. In Dakar and Conakry, which are located on peninsulas, the location of the administrative and business centre on the tip of the land channels vehicles onto a few roads and generates congestion. In Douala, the concentration of traffic on some radial roads is due to the fact that access to the central districts is hampered by a number of barriers, namely the river Wouri, the Bassa industrial estate and the former airport. In all the cities, when there are any, the internal roads in peripheral districts are often untrafficable, justifying the following disillusioned comment from a young unemployed man: "Here, where we live in Wanidara [in the outskirts of Conakry], you can't even talk about roads, even $4 x 4$ s can't get here!'.

The available means of transport have some common characteristics in all cities: household ownership of motorized two-wheelers, and above all cars, is very low, the market share of formal transport enterprises is extremely small, with the informal sector dominating, and public transport services are concentrated on the major paved radial roads. Nevertheless, the urban transport system has developed in a specific manner in each city. Ouagadougou is unique in this respect, as it has long been dominated by two-wheeled vehicles, both bicycles and, in particular, motorized two-wheelers. In the other cities, transport supply is dominated by small-scale entrepreneurs operating with vehicles of different sizes and characteristics (Table 2). Motor vehicle ownership rates are very low and in Dakar, Douala and Conakry, even more than in Bamako and Niamey. These low rates of motorized vehicle ownership among urban households are confirmed by the Demographic and Health Surveys (DHS) that were conducted in the same countries (Table 3). 
Most of the residents of these metropolises thus have no private vehicle (car, motorcycle or bicycle) at their disposal. This applies to more than $90 \%$ of over 13 year-olds in Conakry, Dakar and Douala, $84 \%$ in Niamey, $70 \%$ in Bamako but only $37 \%$ in Ouagadougou because of the large number of two-wheelers. Ouagadougou apart, the population has only two possibilities for travel, walking or public transport.

Table 2. Public transport supply at the time of the surveys

\begin{tabular}{|c|c|c|c|c|c|c|}
\hline & $\begin{array}{c}\text { Bamako } \\
1994\end{array}$ & $\begin{array}{c}\text { Conakry } \\
2003\end{array}$ & $\begin{array}{l}\text { Dakar } \\
2000\end{array}$ & $\begin{array}{c}\text { Douala } \\
2003\end{array}$ & $\begin{array}{c}\text { Niamey } \\
1996\end{array}$ & $\begin{array}{c}\text { Ouaga- } \\
\text { dougou } \\
1992\end{array}$ \\
\hline Motorbike taxi & & & & - & & \\
\hline Shared taxi & • & - & - & - & • & \\
\hline Minibus & - & - & - & 0 & - & \\
\hline Midibus & & & - & 0 & & \\
\hline Bus (formal enterprises) & 0 & 0 & & 0 & 0 & 0 \\
\hline
\end{tabular}

- Major transport mode; $\bigcirc$ Marginal transport mode

Table 3. Percentage of urban households owning motorized vehicles in Burkina Faso, Cameroon, Guinea, Mali, Niger and Senegal (Demographic and Health Surveys)

\begin{tabular}{lcc}
\cline { 2 - 3 } & $\begin{array}{c}\text { Motorized } \\
\text { two wheeler }\end{array}$ & Car \\
\hline Burkina Faso, 2003 & 55.0 & 12.0 \\
Burkina Faso, 2011 & 57.0 & 7.4 \\
\hline Cameroon, 2004 & 8.5 & 8.5 \\
Cameroon, 2010 & 16.4 & 9.5 \\
\hline Guinea, 1999 & 9.2 & 10.9 \\
Guinea, 2005 & 13.9 & 12.1 \\
\hline Mali, 2001 & 33.1 & 13.7 \\
Mali, 2006 & 40.2 & 9.7 \\
\hline Niger, 1998 & 14.0 & 9.1 \\
Niger, 2006 & 17.7 & 9.8 \\
\hline Senegal, 2008-2009 & 8.1 & 2.6 \\
Senegal, 2011 & 10.3 & 3.2 \\
\hline Inc, 2013. Measure DHS Statcompiler. http://www.measuredhs.com, accessed on July 23, 2013.
\end{tabular}

\subsection{A choice between walking...}

The quantitative indicators of daily mobility seem high in relation to the low standards of living (Table 4). The average number of daily trips per person aged 13 and above is between 3.0 and 4.6, which is, like the percentage of the population who make trips (between 87 and 93\%), near to the levels observed in France, for example, in similar surveys (De Solère, 2012). Likewise, travel time budgets, which are approximately one hour, are within international norms (Schafer and Victor, 2000). Douala and Conakry are exceptions here: the average daily travel time in both is one hour thirty minutes because of the heavy congestion.

However, the cities of West and Central Africa are characterized by extremely widespread use of walking and restricted use of mechanized modes (bicycle and motorized modes). The only exception is Ouagadougou, where private vehicles (cars, bicycles and above all motorized two-wheelers) are used for more than half the trips while public transport accounts for only $3 \%$. In the other cities, mechanized modes account for a lower proportion of trips, between 26 
and $43 \%$. Most of the mechanized trips are made with personal modes in Niamey and Bamako, and mainly by public transport in Conakry, Dakar and Douala.

Walking is therefore the most frequent means of transport and is used for up to three-quarters of all trips (Conakry, Dakar), not only for nearby destinations but also for distances of several kilometres. Depending on the city, between 9 and 19\% of walking trips last at least thirty minutes. It is therefore hardly surprising that between a third (Douala, Ouagadougou) and half (Dakar, Niamey) of residents used walking as their only transport mode on the day before the survey (Table 4). Walking dependency is also apparent for individuals who live some distance from the main roads on passenger vehicle routes: "We often have to go near to the PK10 district in order to have easy access to transport. The problem is that it is a long way, 2 to 3 $\mathrm{km}$, and we have to walk" (a female callbox operator living in the distant outskirts of Douala). Although walking is the most important means of transport, it is usually conducted in a hostile environment. The lack of footpaths, the fact that pavements are impassable because informal activities and stalls get in the way of pedestrians, sandy or muddy ground, frequent rutting and the lack of lighting at night are some of the problems that make long walking trips arduous and sometimes dangerous.

Table 4. Indicators of urban mobility and modal use (individuals aged over 13 years, on working weekdays)

\begin{tabular}{|c|c|c|c|c|c|c|}
\hline & Bamako & Conakry & Dakar & Douala & Niamey & $\begin{array}{l}\text { Ouaga- } \\
\text { dougou }\end{array}$ \\
\hline Number of daily trips per person (average) & 3.0 & 3.7 & 3.2 & 4.6 & 4.4 & 3.8 \\
\hline Of which mechanized trips & 1.3 & 1.0 & 0.8 & 1.7 & 1.4 & 2.2 \\
\hline Travel time budget $(\mathrm{min})$ & 62 & 88 & 58 & 88 & 63 & 66 \\
\hline \multicolumn{7}{|l|}{ Modal split (\% of trips) } \\
\hline Walking & 57 & 73 & 74 & 63 & 69 & 42 \\
\hline Proportion of walking trips lasting 30 mins and over (\%) & 19 & 15 & 9 & 11 & 13 & 18 \\
\hline Bicycle & 2 & $\sim 0$ & $\sim 0$ & $\sim 0$ & 1 & 10 \\
\hline Motorized two-wheeler & 15 & $\sim 0$ & 1 & 1 & 7 & 39 \\
\hline Car & 9 & 2 & 3 & 5 & 11 & 6 \\
\hline Public Transport (PT) & 17 & 25 & 22 & 31 & 12 & 3 \\
\hline \multicolumn{7}{|l|}{ Modal mobility profile $^{a}$} \\
\hline Did not travel at all on the previous day & 13 & 11 & 13 & 7 & 9 & 10 \\
\hline Travelled on the previous day, but only on foot & 40 & 46 & 51 & 31 & 52 & 33 \\
\hline Used one or more mechanized modes & 47 & 43 & 36 & 62 & 39 & 57 \\
\hline Of which persons who used $P T$, but no private vehicle ${ }^{\mathrm{b}}$ & 18 & 40 & 29 & 53 & 19 & 6 \\
\hline Of which persons who used one or more private vehicles & 29 & 3 & 7 & 9 & 21 & 51 \\
\hline
\end{tabular}

${ }^{a}$ As for the other indicators, these profiles are based on travel the day before the survey day, from Monday to Friday.

${ }^{\mathrm{b}}$ Car, motorized two-wheeler or bicycle/cart.

Everyone walks to some extent, but if it is necessary "to trust your feet" (Kinda, 1987: 491) it is for want of a better alternative, and some groups are more dependent on walking than others, frequently to the exclusion of any other transport mode during the day. The proportion of such captive walkers is particularly high among women, children and young persons, whether in education or not, but also among apprentices, small traders and the working poor more generally. Vehicle availability within households also depends on trade-offs that are unfavourable to individuals with limited personal resources due to the high tension on household budgets. Restricted access to vehicles of any sort is thus an intrinsic characteristic of urban dwellers. 


\section{3. ...or paying}

We cannot fully understand the universal use of walking if we only consider the difficulties of access to mechanized transport modes that result from their poor quality and scarcity. We also need to take account of their high cost. Depending on the city, urban travel absorbs between 16 and $20 \%$ of household income, with the distribution of expenditure between different modes depending on local factors (Table 5).

Table 5. Percentage of household budget spent on daily mobility

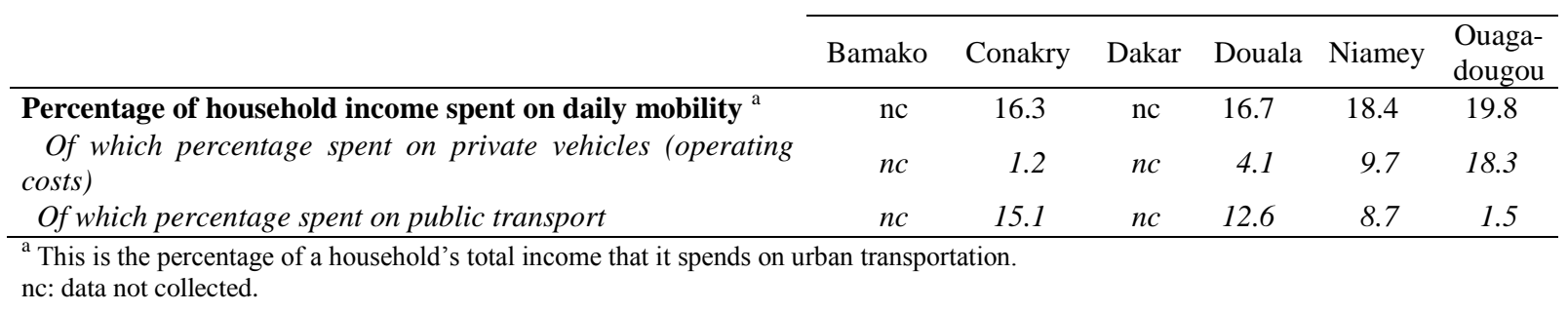

While access to private vehicles is hampered by high purchase and maintenance costs, economic barriers also restrict access to public transport. In the absence of public subsidies, the fares charged by private operators are high in comparison with users' incomes meaning that public transport expenditure is socially regressive. Thus, in Niamey, the households who belong to the wealthiest quintile, whose motor vehicle ownership is much higher, spend twice as much on public transport than the poorest quintile. The cost of public transport seems to weigh particularly heavily on households which have both low incomes and/or who live in peripheral areas that are distant and/or isolated (Diaz Olvera et al., 2008). In Conakry, public transport users spend a third more money on each trip and twice as much time (56 minutes as opposed to 30) if they live in the distant outskirts rather than in the centre. Likewise, in Douala, when they need to use public transport, individuals living on the right bank of the Wouri spend half as much more time and money as those who live on the left bank, where most urban facilities are concentrated.

The result is that public transport use and expenditure are calculated extremely carefully with reference to the individual's available financial resources at the time, as in the case of this young itinerant hairdresser from Conakry: "Each time I have to travel, it takes me several days to find [the money for] my fare". Public transport is rare, costly and exhausting, in particular in rush hours when demand exceeds supply. The result is a recurring need to reduce expenditure by adjusting travel behaviours frequently and in many ways:

- choosing the modes with the most affordable fares,

- negotiating the fare in off-peak periods,

- in the case of long trips (with connections or not), making part of the journey on foot,

- making the outward journey on public transport and the return journey on foot (or the other way round),

- chaining several activities together at the destination,

- forgoing some activities because of an inability to pay the fare.

Such adjustments due to strong budgetary pressures are not unique to African cities, e.g. poor families in Santiago de Chile decide to walk to avoid paying for public transport (Ureta, 2008). They are, however, particularly widespread in Africa, where factors apart from the shortage of transport services and strong monetary pressures have a major influence on individuals' out-of-home activities. 


\section{Travelling in order to fulfil day-to-day obligations}

The distribution of trips according to major types of out-of-home activity differs from one city to another, Conakry being the most atypical case, with the highest share of household management trips (Table 6). In the other cities, work and education are responsible for the highest percentage of trips (37 to 48\%). In Dakar, and even more in Douala, household management is the second most important trip purpose, while in Bamako, Niamey and Ouagadougou, residents travel almost as much for this purpose as for social life. Apart from these local differences, examining the three major types of out-of-home activities reveals certain tendencies in the way individuals adapt to the constraints due to poverty.

Table 6. Distribution of urban trips according to the major types of activity (percentage of trips on working weekdays of individuals aged over 13 years)

\begin{tabular}{lccccc}
\cline { 2 - 5 } & Bamako & Conakry & Dakar & $\begin{array}{c}\text { Douala } \\
\text { Niamey }\end{array}$ & $\begin{array}{c}\text { Ouaga- } \\
\text { dougou }\end{array}$ \\
\hline Work, education & 48 & 32 & 37 & 39 & 41 \\
Household management and personal business $^{\text {a }}$ & 25 & 41 & 34 & 35 & 30 \\
Social life, leisure $^{b}$ & 27 & 27 & 29 & 26 & 29 \\
Includes: shopping, supplies (water, wood...), religious practices, health care, formalities, services and escorting. \\
Includes: visits (to the family, friends and neighbours), ceremonies, activities in associations and leisure activities.
\end{tabular}

\subsection{Travelling to places of work or education}

Travel that is related to work and education is determined by the operation and spatial organization of the labour market and the educational system. In Conakry, which is the city where such trips account for the smallest percentage, the economic context was particularly unfavourable at the time of the survey: only $67 \%$ of the respondents of between 25 and 50 years of age reported having worked on at least one day in the last thirty days (the figure was $78 \%$ in Douala in the same year). In addition, the start of the school year was delayed in Conakry and spread out during the survey period.

Some home-to-school trips were amongst the longest journeys of individuals aged over 13 years. Travelling to secondary schools requires long trips across the city, and this is even more the case for higher education institutions. The fatigue due to these long trips is further increased by the shortcomings in transport supply. In Dar es Salaam, students are often not allowed to board the dalasdalas during peak periods as they pay half fare and the operators receive no subsidy to compensate for this (Rizzo, 2002). Children and young people face many hazards in their daily travel, whether this is on foot or motorized transport: there are road safety and physical danger issues, as well as the possibility of violence, abuse and harassment from transport vehicle operators (Porter et al., 2010, describe cases in Ghana, Malawi and South Africa).

Commuting generates a higher share of long trips than education. Depending on the city, between 32 and $56 \%$ of workers work "in the city" and far from home. In most cases, these individuals are employees in the public or private formal sector, particularly in the city centre (Table 7). For such trips the use of motorized modes would seem logical, but the empirical data show that a significant proportion of these individuals still walk. Depending on the city, between 6 and $23 \%$ of the workers who work "in the city" walk to work, like this breadwinner who works for a security firm in Conakry: "Every day, I walk along the Conakry-Niger railway tracks to get to work [5 $\mathrm{km}$ away] and back. I'm forced to do this because I can't 
afford the fare to work". The proportion of workers who work "in the city" is higher in Douala and Ouagadougou, once again due to the greater travel flexibility provided by motorized two-wheelers. Furthermore, in Douala, the presence of several business zones (port, markets, and industries) in central districts generates a large number of formal and informal jobs.

Table 7. Job location and modal use for travelling to work "in the city" (percentage of trips on working weekdays for individuals aged over 13 years)

\begin{tabular}{|c|c|c|c|c|c|c|}
\hline & Bamako & Conakry & Dakar & Douala & Niamey & $\begin{array}{l}\text { Ouaga- } \\
\text { dougou }\end{array}$ \\
\hline \multicolumn{7}{|l|}{ Place of work (\% of working population) } \\
\hline Itinerant (hawker, employed in transport...) & 8 & 8 & 13 & 4 & 8 & nc \\
\hline At home & \multirow{2}{*}{$40^{*}$} & 18 & 13 & 14 & 17 & \multirow{2}{*}{$26^{*}$} \\
\hline In district of residence & & 35 & 26 & 13 & 17 & \\
\hline In neighbouring district & 16 & 8 & 7 & 13 & 11 & 24 \\
\hline "In the city" (in another district) & 36 & 32 & 41 & 56 & 47 & 50 \\
\hline \multicolumn{7}{|c|}{ Transport mode used by individuals working in the city (\% of working population working in the city) } \\
\hline Walking & 8 & 19 & 23 & 18 & 22 & 6 \\
\hline Public transport & 33 & 76 & 58 & 70 & 28 & 4 \\
\hline Private vehicle & 59 & 5 & 12 & 12 & 50 & 90 \\
\hline
\end{tabular}

The case of the workplace location of traders in Conakry clearly shows the economic issues that relate to access to the city. The income of poor self-employed traders who work in the city and travel there by public transport is on average $40 \%$ higher than that of traders who stay in their residential neighbourhood and travel to work on foot ${ }^{2}$. Their "net" income is still $20 \%$ higher once transport costs have been deducted (Sitrass, 2004a). The influence of the workplace location on the profitability of the activity is expressed thus by this trader who commutes by minibus: "In spite of the transport difficulties, I prefer to sell on Tanènè market because it's a good place to sell the local rice. It's always possible to sell in your own neighbourhood, but you can't be sure of finding as many customers as on the large markets". These findings confirm those from the different context of major Indian metropolises, as in Chennai, where public transport provision is low, poor residents have better and cheaper access to jobs when they live in the districts near the centre than in the outskirts (Srinivasan and Rogers, 2005). Similarly, poorly qualified workers in the core city of the metropolis of Mumbai have access to better paid jobs near their home than those living in peripheral zones (Baker et al., 2005).

With other individual characteristics (notably gender, life-course phase, family organization and ethnicity) and the types of goods sold, the trade-offs can lead to a preference for proximity (Diaz Olvera et al., 2001; Mandel, 2004). Thus, still in Conakry, another rice seller who sells 500 metres away from her home states: "In Gbessia, selling rice does not bring in much. [...] I used to sell on Tombo market [the central market], but because of the transport difficulties I looked for a stall on Gbessia market. Even if I have the opportunity to sell elsewhere, I prefer to stay here, as it's nearer my home". Selling near her home means that this woman, who has two children at school, can better reconcile her family and professional activities, but does not offer any possibility of increasing her income. The survey in the

\footnotetext{
${ }^{2}$ Individual income was rigorously identified in the Conakry and Douala Household Travel Surveys. Particular attention was paid to the collection of income data starting from the training of interviewers to ensure they were aware about variable income payment frequencies, the difference between turnover and profit, and the need to limit the risk of double counting when several members of the household take part in the same economic activity.
} 
capital of Guinea shows that compared to men's, women's jobs are more frequently located at a short distance from home, as has also been observed in Nairobi (Salon and Guliany, 2010). In spite of the possibility of earning more money, the inconvenience, cost and duration of travel combine to dissuade people from working in the city.

While "money seeking" leads some workers to make long trips to their workplace and for a number of them to engage in several livelihood activities (increasing their trips proportionately), travel difficulties also lead some individuals to blur the boundaries between home and workplace. "Family residential systems" (Le Bris et al., 1987) may help to reduce daily travel distances by providing temporary accommodation for a period (ArdayfioSchandorf et al., 2012; Grieco et al., 1996). More drastically, working at home (as do between one and two workers out of ten, see Table 6) provides a way of saving the rent of business premises, allows poor households to diversify their sources of income (Turner and Kwakye, 1996) and enables women to manage the dual pressures exerted by the family and their occupation (Rondeau and Bouchard, 2007). On the other hand, the place of work can sometimes be used as a residence, at least a temporary one, and poor workers sleep at their place of work, as in the case of the kayayoo, young female market porters (Grieco et al., 1996) and the veranda boys (Bertrand, 2010) in Accra.

The dominance of the informal sector in African urban economies therefore has ambivalent impacts on daily mobility. But the vast majority of urban dwellers are forced to adjust their behaviours in order to find a job.

\subsection{Making up for the lack of facilities}

Depending on the city, household management and personal trips account for between $25 \%$ (Bamako, Ouagadougou) and 41\% (Conakry) of all trips of individuals aged over 13 years.

The health sector shows clearly how geographical and economic difficulties with regard to access to services add to one another (Diaz Olvera et al., 2011). Public health facilities, although generally financially affordable, are of insufficient quality and too few in peripheral districts. The shortcomings in public health services are partly compensated for by private structures that are usually of higher quality, but these too are unequally distributed over the urban area and significantly more expensive. In Douala, for example, private healthcare centres and clinics are widely distributed within the city, but they are less common in the districts with poor access, far from public transport routes. Accessibility problems thus exacerbate the difficulties in obtaining healthcare that are caused by the deficiencies inherent in the healthcare sector and appear to have a particularly severe impact on the residents of peripheral zones with poor access (Sverdlik, 2011).

The organization and duration of domestic activities, whether inside or outside the home, above all raise the issue of the social distribution of roles, which is strongly linked to the individual's gender and status within the household. The tasks of shopping for food and preparing meals fall most frequently on the women, whether they remain at home or have a professional activity, and they are sometimes assisted by a young female family member or a servant. Trips that are made in order to pray (more than one in ten trips in Conakry and Niamey) are, in Muslim countries, mainly made by men. In all the cities, fetching water is usually performed by women and children. "We use well water. In the morning, before going to school our child collects the water and I wash some things, go to the market, and come back home to prepare [the meal]". The organization described by this fritter seller who lives in a central district of Douala, is far from unique. Fetching water, which is more frequent in 
unplanned districts, may represent as much as $5 \%$ of all the trips made in a city. Porter et al. (2010) have thus shown that in Abura, a district of Cape Coast (in Ghana), 71\% of girls and $82 \%$ of boys participated daily in this activity during the week before the survey was conducted. When women's seclusion is the norm, the wives' out-of-home activities are carried out by their husband or children. This is responsible not only for some differences in travel behaviours between cities, but also between neighbourhoods in the same city. Thus, in Niamey, the wives who did not leave home the day before the survey and who lived in unplanned peripheral districts mentioned religious principles twice as often as those who lived in other areas.

A high proportion of household management and personal business trips are for purchasing food, which is the largest item of expenditure for households in African cities (Koriko and Torelli, 2005). Food is often purchased in small quantities, on a daily basis. The location and accessibility of where it is purchased are therefore an important issue for households. The surveys reveal that practices vary considerably according to residential location. Seven out of ten households in Douala and almost nine out of ten in Conakry walk to the market, although every district does not have one. Even when the market is some distance away, the majority of urban dwellers walk there. This applies particularly often to individuals who live in areas that have been recently urbanized or that are located some distance from the centre. Shopping in the central market becomes more and more exceptional the further away the individual's home is from it, as this unmarried mother from Douala states: "I spend more on transport here because in Brazzaville [central district] we could walk to the central market, which is impossible from here because of the distance". Leaving a dwelling in a relatively central district for cheaper lodgings in the outskirts has the certain consequence of making access to shopping areas more difficult.

\subsection{Keeping in touch}

Sociability and leisure are responsible for more than a quarter of urban trips, even though the surveys did not cover travel on Sundays. A very small proportion of these trips consists of leisure trips and the large majority of travel is related to visits of all types, participation in ceremonies (from baptisms to funerals) and meetings of associations and social networks.

In African cities, integration within social networks and face-to-face socializing are usually a necessity. As this driver from Conakry states: "I also see the members of my extended family. You know, in Africa, you have to go and see your family, talk about any problems and see what has to be done". Economic difficulties provide a strong incentive for maintaining a network of contacts who may be "useful" in the case of need. In many other cases, the monetary benefit may be immediate. The average proportion of household income that comes from gifts from a person outside the household is $6 \%$ in Douala and 11\% in Conakry, and it is even higher among poor households (Sitrass, 2004a, 2004b). In the absence of a system of institutionalized solidarity, maintaining a network of ties makes it possible to finance healthcare, pay for children's schooling or help to find a job (Marie, 1997).

A safety net of this type can only come into play if the individual regularly takes part in meetings and discussions (see Cass et al., 2005, for similar observations regarding countries of the North). The caring that urban dwellers show by making regular visits to family and friends allows them to seek support or to symbolically repay the support they have already received. This applies to the frequent visits paid by unemployed young people in Accra to relatives, friends and acquaintances at their workplace as part of job seeking tactics in a context where unemployment is high (Langevang and Gough, 2009). But, as it is usually the 
social junior who visits an older person, it is increasingly difficult for the first to fulfil his/her social obligations at a time when incomes are tending to fall (Lecarme-Frassy, 2000). Of course, the host very often feels obliged to pay the cost of transport. However, this practice, which concretizes the links between the two individuals, becomes less frequent when resources become scarcer and redistribution mechanisms are focused on the closest family members (Leimdorfer and Marie, 2003).

Many poor urban dwellers mention the difficulty of keeping up with visits and participation in associations or ceremonies due to the fact that networks of ties are frequently dispersed throughout the urban area and travel is difficult. This is the case in Douala, as reported by this 23 year-old female secondary school student in Bonaberi: "I mainly go out when I get an invitation or when I have to visit a family member. I do this only four times a month, mainly because I haven't got enough money". However, if, as in the previous example, these difficulties weaken social ties in the long term, the inadequacies in transport services sometimes have negative impacts in the very short term, such as in the case of this female meat seller in Conakry: "I belong to a group. [We meet together] every Thursday, in the outskirts. One day, I waited from 4 pm to $7 \mathrm{pm}$ but no transport came to take me to our group leader's. I had to pay a fine of 4,000 Guinea Francs at the next meeting".

It is the residents of the most distant districts who suffer most from the shortcomings in transport supply. Is there not a danger that sociability will become spatially confined to individuals' residential neighbourhoods, leaving the poor to live "amongst themselves" (Moser and Holland, 1997)? In this case, individuals' safety nets would become extremely weak, at a time when they are most needed.

The rise of the mobile telephone has the potential to mitigate some travel difficulties and preserve a degree of social integration. Porter et al. (2012) thus show the major role the mobile phone has started to play recently as a means of avoiding long trips and keeping in touch with family members. They also highlight that the mobile telephone helps young persons (9-18 year-olds) escape from social constraints which pose travel problems for them. We can already detect the first signs of such changes in this comment made by a female riceseller on Tanene market in Conakry: "I would like to meet my friends and very close family, but if I can't I always take their phone numbers in order to call them".

\subsection{Travelling outside one's neighbourhood: seeking out better resources}

To what extent does the low level of access to mechanized transport modes limit visits to urban amenities and affect the daily life of different population groups? In addition to the examples we have given above, two indicators provide us with a more comprehensive measure of the importance of withdrawal into the residential neighbourhood and the difficulty of travelling into the city (Table 8).

The first indicator describes the spatial range of each trip, specifying the districts of origin and destination. With, once again, the exception of Ouagadougou, by far the majority of trips are short. Between half and two-thirds of the trips are near home (in the district or to a neighbouring district). Such rates are of course consistent with the dominance of walking which is the most frequently-used mode. In Ouagadougou, however, the high availability of private vehicles makes it possible to avoid walking, even for local trips, as is the case with passenger car use in the countries of the North. 
Table 8. Spatial indicators of urban mobility (percentage of trips on working weekdays of individuals aged over 13 years)

\begin{tabular}{|c|c|c|c|c|c|c|}
\hline & Bamako & Conakry & Dakar & Douala & Niamey & $\begin{array}{l}\text { Ouaga- } \\
\text { dougou }\end{array}$ \\
\hline \multicolumn{7}{|l|}{ Spatial distribution of trips } \\
\hline Within residential district & 39 & 54 & 58 & 39 & 44 & 41 \\
\hline From the residential district to a neighbouring district & 23 & 12 & 8 & 13 & 13 & 22 \\
\hline From the residential district to a non-neighbouring district & 28 & 27 & 29 & 30 & 33 & 29 \\
\hline No link with the residential district & 10 & 7 & 5 & 18 & 10 & 8 \\
\hline \multicolumn{7}{|c|}{ Frequentation of the city centre by urban dwellers who do not live there } \\
\hline Trips to or from the centre & 25 & 4 & 9 & 13 & 16 & 22 \\
\hline Internal trips within the centre & 4 & 1 & 1 & 5 & 2 & 2 \\
\hline Other trips & 71 & 95 & 90 & 82 & 82 & 76 \\
\hline
\end{tabular}

The six cities are, to different degrees, characterized by a relative concentration of economic, commercial and administrative activities in their central districts. Even with the emergence of a number of secondary centres in some conurbations, access to the city centre remains important as it is there that the most highly paid jobs are located, in both the modern and informal sectors. The advantages of the central zones are not restricted to jobs, for example, in most cases the unit price of purchases is also lower. However, if we exclude the residents of the city centre, the second indicator (Table 8) shows that only between 5 and $29 \%$ of the daily trips have one end in the central districts. In spite of their specific amenities, jobs, shops or administrations, the vast majority of urban dwellers visit the city centre rarely in their daily lives. This confirms the importance of the areas around the home in daily travel patterns and the fact that a large proportion of the urban population is forced to live in restricted areas.

\section{Conclusion}

It is obvious that a retrospective analysis of travel behaviours in six cities located in West and Central Africa based on household travel surveys that are spread over more than 10 years cannot provide a precise measurement of the present-day practices. Such surveys can only provide snapshots of travel behaviours, and only periodic surveys that apply a similar methodology would allow us to perceive the dynamics of daily mobility and, more broadly, general lifestyles.

However, the changes that are currently affecting urban systems seem unlikely to reduce the difficulties urban dwellers were experiencing at the time of the surveys in order to satisfy their mobility needs and the resulting restrictions to access to the city. Even if the macroeconomic indicators have been improving in recent years, poverty continues to be a major problem, as does the poor provision of basic services in neighbourhoods. Household vehicle ownership is still low, and mostly involves motorized two-wheelers which are much less expensive than cars to purchase and run. At the same time, public transport remains inadequate and is frequently too expensive. Urban sprawl is continuing and daily mobility probably is as necessary and complex to perform as at the time of the surveys, even if the rise of the mobile telephone may partially modify the links between trips and telecommunications.

In a context where information on daily mobility is scarce, and databases which enable us to compare different cities extremely so, this analysis reveals some major structural tendencies. Only a minority of well-to-do urban dwellers have access to personal transport modes. The shortcomings of public transport services (an insufficient level of supply, poor quality of service, minimal coordination between operators and the absence of integrated fares) restrict 
the ability of urban dwellers, particularly poor ones, to travel outside their neighbourhood. Consequently, the large majority of urban dwellers, in particular housewives and schoolchildren, walk a great deal in order to carry out their usual activities. They spend their days near their home. Even if some people manage to find jobs that are some distance away from their home, economic and social interactions at the scale of the city are much less common than interactions that involve small distances within the neighbourhood or its immediate surroundings.

Thus, for the majority of urban dwellers, the possibilities for developing human capital must depend on the local provision of facilities and services. The question of access to the city is particularly important for urban dwellers with limited incomes, for those who belong to a household which resides in an outlying area with poor access, and for the large number of individuals who fall into both groups. Like the health and education sectors, transport is affected by sector-specific malfunctions that are exacerbated by difficult access to mechanized modes of transport and the poor conditions under which trips are made. At a time when current social inequalities are apparent in travel behaviour (e.g. differentiated use of transport modes, restricted access to urban amenities), the current failings in the transport system play a major role in reproducing and amplifying these inequalities in the major cities of sub-Saharan Africa.

\section{Acknowledgements}

Our thanks go to three anonymous referees for their insightful comments on the earlier draft of this paper.

\section{References}

Ardayfio-Schandorf, E., Yankson, P.W.K., Bertrand, M., 2012. The Mobile City of Accra. Urban Families, Housing and Residential Practices. CODESRIA, Dakar.

Baker, J., Basu, R., Cropper, M., Lall, S., Takeuchi, A., 2005. Urban Poverty and Transport. The Case of Mumbai. Policy Research Working Paper 3693, World Bank, Washington, DC.

Beauchemin, C., Bocquier, P., 2004. Migration and urbanization in francophone West Africa: a review of the recent empirical evidence. Urban Studies, 41 (1), 2245-2272.

Behrens, R., Diaz Olvera, L., Plat, D., Pochet, P., 2006. Collection of passenger travel data in sub-Saharan African cities: towards improving survey instruments and procedures. Transport Policy, 31 (1), 85-96.

Bertrand, M., 2010. De l'accès au logement à la relation domicile-travail: Enjeux sociaux et spatiaux des mobilités dans la région du grand Accra (Ghana). Revue Tiers Monde 201, 87-106.

Bryceson, D.F., Mbara, T.C. Maunder, D., 2003. Livelihoods, daily mobility and poverty in sub-Saharan Africa. Transport Reviews 23 (2), 177-196.

Cass, N., Shove, E., Urry, J., 2005. Social exclusion, mobility and access. The Sociological Review 53 (3), 539 555.

De Solère, R. (Dir.), 2012. La mobilité urbaine en France. Enseignements des années 2000-2010. Certu, Lyon.

Diaz Olvera, L., Plat, D., Pochet, P., 1998. Villes africaines au quotidien. LET, Etudes \& Recherches 9, Lyon.

Diaz Olvera, L., Plat, D., Pochet, P., 1999. Les déplacements quotidiens des Niaméens. Un état des lieux. LET, Lyon.

Diaz Olvera, L., Plat, D., Pochet, P., 2001. Immobiles ou invisibles? Les mobilités quotidiennes des femmes à Bamako et à Ouagadougou. Canadian Journal of Development Studies/Revue canadienne d'études du développement 22 (1), 115-134. 
Diaz Olvera, L., Plat, D., Pochet, P., 2008. Household transport expenditure in sub-Saharan African cities: measurement and analysis. Journal of Transport Geography 16 (1), 1-13.

Diaz Olvera, L., Plat, D., Pochet, P., 2011. Se déplacer pour se soigner. Pratiques et obstacles à Conakry et Douala. Cahiers de Géographie du Québec 55 (156), 555-573.

Dimitriou, H.T., Gakenheimer, R., 2011. Conclusions: emergent crucial themes. In: Dimitriou, H.T., Gakenheimer, R. (Eds.), Urban Transport in the Developing World. A Handbook of Policy and Practice. Edward Elgar, Cheltenham-Northampton, pp. 589-603.

Dorier-Apprill, E., Kouvouama, A., Apprill, Ch., 1998. Vivre à Brazzaville, modernité urbaine et crise au quotidien. Karthala, Paris.

ENSUP, 1993. Bamako. CRET-Université de Bordeaux, Talence.

Grieco, M., Apt, N., Turner, J., 1996. At Christmas and on Rainy Days. Transport, Travel and the Female Traders of Accra. Avebury, Hampshire.

Groupe Huit-Bceom, 2003. Etude de faisabilité d'un programme prioritaire d'aménagement des quartiers souséquipés de Conakry. Rapport de phase 1. Direction Nationale de l'Aménagement du Territoire et de l'Urbanisme du Ministère de l'Urbanisme et de l'Habitat de la République de Guinée, Conakry.

Jaglin, S., 1994. Why mobilize town dwellers - joint management in Ouagadougou, 1983-1990. Environment and Urbanization 6 (2), 111-132.

Kinda, F., 1987. Ménages populaires à Ouagadougou. Thèse de doctorat en sociologie, Université de Nantes.

Koriko, O., Torelli, C., 2005. La consommation et le rôle du secteur informel dans la satisfaction des besoins des ménages, enquête 1-2-3, phase 3. Stateco 99, 89-115.

Langevang, T., Gough, K.V., 2009. Survival through movement: the mobility of urban youth in Ghana. Social and Cultural Geography 10 (7), 741-756.

Lecarme-Frassy, M., 2000. Marchandes dakaroises entre maison et marché. Approche anthropologique. L'Harmattan, Paris.

Leimdorfer, F., Marie, A. (Dir.), 2003. L'Afrique des citadins. Sociétés civiles en chantier (Abidjan, Dakar). L'Harmattan, Paris.

Le Bris, E., Marie, A., Osmont, A., Sinou, A., 1987. Famille et résidence dans les villes africaines. Dakar, Bamako, Saint-Louis, Lomé. L'Harmattan, Paris.

Lucas, K., 2011. Making the connections between transport disadvantage and the social exclusion of low income populations in the Tshwane Region of South Africa. Journal of Transport Geography 19 (6), 1320-1334.

Mandel, J.L., 2004. Mobility matters: Women's livelihood strategies in Porto Novo, Benin. Gender, Place and Culture 11 (2), 257-287.

Marie, A. (Ed.), 1997. L'Afrique des individus. Karthala, Paris.

Moser, C., Holland, J., 1997. Household Responses to Poverty and Vulnerability. Volume 4. Confronting Crisis in Chawama, Lusaka, Zambia. Urban Management Program Policy Paper 24, World Bank, Washington, DC.

Myers, G.A., 2005. Disposable cities: garbage, governance and sustainable development in urban Africa. Ashgate, Aldershot.

Macro International Inc, 2013. Measure DHS Statcompiler. http://www.measuredhs.com, accessed on July 23, 2013.

Orfeuil, J.-P., 2000. L'évolution de la mobilité quotidienne. Comprendre les dynamiques, éclairer les controverses. Synthèse 37, Inrets, Arcueil.

Porter, G., Hampshire, K., Abane, A., Robson, E., Munthali, A., Mashiri, M., Tanle, A., 2010. Moving young lives: mobility, immobility and inter-generational tensions in urban Africa. Geoforum 41 (5), 796-804.

Porter, G., Hampshire, K., Abane, A., Munthali, A., Robson, E., Mashiri, M., Tanle, A., 2012. Youth, mobility and mobile phones in Africa: findings from a three-country study. Information Technology for Development 18 (2), 145-162.

Potts, D., 2009. The slowing of sub-Saharan Africa's urbanization: evidence and implications for urban livelihoods. Environment and Urbanization 21 (1), 253-259. 
Rakodi, C., 2005. The urban challenge in Africa. In: Keiner, M., Koll-Schretzenmayr, M., Schmid, W.A. (Eds), Managing Urban Futures. Sustainability and Urban Growth in Developing Countries. Ashgate, Farnham, pp. 4770 .

Rizzo, M., 2002. Being taken for a ride: privatisation of the Dar es Salaam transport system 1983-1998. Journal of Modern African Studies 40 (1), 133-157.

Rondeau, Ch., Bouchard, H., 2007. Commerçantes et épouses à Dakar et Bamako. L'Harmattan, Paris.

Salon, D., Gulyani, S., 2010. Mobility, poverty, and gender: travel 'choices' of slum residents in Nairobi, Kenya. Transport Reviews 30 (5), 641-657.

Schafer, A., Victor, D.G., 2000. The future mobility of the world population. Transportation Research A 34 (3), $171-205$

Sitrass, 2004a. Poverty and Urban Mobility in Conakry. Final report. SSATP n 09/04/Ckr, World Bank, Washington, DC. http://www4.worldbank.org/afr/ssatp/Resources/PapersNotes/Conakry.pdf

Sitrass, 2004b. Poverty and Urban Mobility in Douala. Final report. SSATP n 09/04/Dla, World Bank, Washington, DC. http://www4.worldbank.org/afr/ssatp/Resources/PapersNotes/Douala.pdf

Srinivasan, S., Rogers, P., 2005. Travel behavior of low-income residents: studying two contrasting locations in the city of Chennai, India. Journal of Transport Geography 13 (3), 265-274.

Sverdlik A., 2011. Ill-health and poverty: a literature review on health in informal settlements. Environment and Urbanization 23 (1), 123-155.

Syscom, 2001. Enquête sur la mobilité, le transport et les services urbains à Dakar (EMTSU). Rapport d'analyse pour le CETUD. Syscom, Dakar.

Turner, J., Kwakye, E., 1996. Transport and survival strategies in a developing economy: case evidence from Accra, Ghana. Journal of Transport Geography 4 (3), 161-168.

Ureta, S., 2008. To move or not to move? Social exclusion, accessibility and daily mobility among the low income population in Santiago, Chile. Mobilities 3 (2), 269-289.

Vasconcellos, E.A., 2001. Urban Transport, environment and equity. The case for developing countries. Earthscan, London. 